Research Article

Hannah Edlund*

\title{
An analysis of American public libraries' policies on patron use of Internet pornography
}

https://doi.org/10.1515/opis-2020-0005

Received October 31, 2019; accepted February 14, 2020

\begin{abstract}
Drawing on and expanding previous graduate course research, this paper investigated and analyzed public libraries' policies regarding patron use of legal, visual Internet pornography on public computers. Pornographic imagery that falls within legal boundaries is protected by the First Amendment. Incidents of, and library responses to, pornography viewing are not a new issue and have caused turmoil across the field of library and information science. In an attempt to understand the problem, the research question asks: how do public libraries respond to patrons viewing legal Internet pornography, while upholding First Amendment rights as well as the Children's Internet Protection Act (CIPA) and other legal requirements? Libraries tread a fine line to protect First Amendment rights, respect community laws, and uphold CIPA. Research indicated that responding to Internet pornography use in public libraries is heavily dependent on individual, community and library values. Policies are more likely to prohibit patrons from accessing Internet pornography, and most libraries have at least some Internet filtering software restricting what content may be accessed on public use computers. However, evidence also suggests that regardless of policy or filters, library staff will at some point encounter a patron accessing Internet pornography.
\end{abstract}

Keywords: Children's Internet Protection Act (CIPA), Internet pornography, First Amendment, Internet filters, public libraries

\section{Introduction}

Initially, this research was graduate coursework which aimed to discover an "ultimate policy" to meet everyone's needs. Following completion of original data collection, it became clear there is no one simplified policy regarding patrons viewing Internet pornography in U.S. public libraries. Later, the topic was resurrected outside the classroom for further, expanded research. New qualitative, semi-structured interviews with librarians and library employees were conducted to address information gaps discovered in the first round of data collection. Questions from the original quantitative online survey were re-formatted for clarity and precision, and the new survey was conducted with a larger sample set. Previous quantitative data was used only for reference, and not included in this analysis.

To begin, a definition of "pornography" or "pornographic images" must be established in order to determine what is considered legal. According to Cornell Law School's Legal Information Institute's Wex legal dictionary, pornography is "photographs, films, books, or other material depicting erotic or sexual acts designed to cause sexual arousal. Pornography is protected by the First Amendment free speech provisions unless it is found to be obscene” (LII/Legal Information Institute, paragraph 1). Noticeably, First

*Corresponding author, Hannah Edlund, University of Washington iSchool, MLIS Candidate, 5240 Jefferson St., Houston, TX 77023, United States, E-mail: hgedlund@uw.edu 
Amendment protection is not extended to material judged obscene; nor does it protect pornographic content including minors (child pornography) (Obscenity, 2015). Thus, we must make a careful distinction: not all pornography is obscene, and not all obscenity is pornographic. Following three Supreme Court cases (Miller v. California, 1973; Smith v. United States, 1977; and Pope v. Illinois, 1987), the Supreme Court established a three-pronged test to identify obscenity, called the Miller test after the 1973 Miller case. Anything that meets the following three criteria is obscene if: 1 . The material is considered, in whole, by average adult community standards, to appeal to prurient interests; 2 . The material offensively describes or depicts sexual conduct, by average adult community standards; and 3 . The material, as a whole, lacks serious scientific, artistic, literary or political value, according to a reasonable person (Citizen's guide, 2015). But as Fix (2016) argues, the Miller test is insufficiently worded to create a universal standard. His studies exemplify a lack of community consensus concerning a range of pornographic material, even among selected subjectsundergraduate students-ostensibly a group with greater similarities than the wider population. The potentially subjective nature of the Miller test is echoed in other legislature regarding sexual materials, and also in policies and rules concerning appropriate library behavior.

Other federal laws directly affect viewing legal Internet pornography in public libraries. The 2001 Children's Internet Protection Act (CIPA) requires all public libraries and public schools to have an Internet safety policy with protection measures that block or filter visual content that is obscene, child pornography, or deemed harmful to minors in order to receive Library Services and Technology Act (LSTA) or Universal Service discounts (E-rate) (FCC, 2011). The American Library Association (ALA) and other library groups challenged CIPA on the grounds that requiring publicly-funded libraries to block Internet content was a violation of First Amendment rights and an undue burden. The Supreme Court decided in favor of CIPA and upheld the legislation, ending court battles in 2003 (ALA, 2010). While requiring only computers accessible to minors to have filters or blocks ${ }^{1}$, many libraries have found it difficult or impractical to provide unfiltered Internet access exclusively to adult patrons. Therefore, many libraries may have filtering or other similar software on all public computers, effectively limiting what content adults can access. Even libraries providing adults over 17 years of age the option to turn off or otherwise temporarily remove Internet filters risk inadvertent censorship, because not all patrons may know to ask, or feel comfortable making that request. CIPA allows disabling filters for conducting "bona fide research", but library staff is left to decide what constitutes a "bona fide research" or other permissible purpose. Without specifically defining what may be considered appropriate bone fide research, CIPA guidelines for filter removal are vague; blindly determining qualifications creates a difficult situation for library staff and patrons (Jaeger, Bertot \& McClure, 2004).

Certain states' laws regulate public and school library implementation of filters and other Internet protection measures on behalf of minors. Many echo or complement CIPA, but most are concerned with creating Internet use policies, rather than blocking or censoring potentially harmful or objectionable content (National Conference of State Legislatures [NCSL], 2018). As a result of both federal and state legislative mandates, some libraries overcompensate, and filters prohibit access to material that is protected and not objectionable, often unrelated to the intended targeted content. In the years following CIPA's passing, multiple studies concluded that this reaction was, contrary to the Supreme Court's opinion, negatively impacting First Amendment rights of adults and minors by blocking access to protected speech, ideas, and expressions (Batch, 2015; ALA, 2015; Batch, 2014; Caldwell-Stone, 2013; Kranich, 2004; Skaggs, 2003).

Numerous logical arguments in favor of installing filtering or blocking software on all public-use computers exist. Some websites featuring CIPA-specified content (sexual, obscene, or pornographic images) have problematic origins or are platforms for illegal computer activity. Image and video downloads have long been notorious for hiding harmful components, such as malware, spyware or viruses, from unsuspecting users. Most basic computer protection software packages prevent casual users from a range of Internet dangers, but they are imperfect. If library patrons ignorant of potential malware are unable to access sites that tend to carry malicious components, then filtering or blocking software can serve as

1 The FCC guidelines webpage differs from the wording of the actual CIPA legislation, which states that all computers, regardless of availability to minors, must comply with technology protection measures and safety policy requirements (McCain, 1999). 
a protective measure; the right of freedom of expression does not grant the right to harm others or their property.

Yet at the crux of the argument against CIPA and Internet filtering is available software's fallibility. At the time of CIPA's passing and subsequent Supreme Court decision to uphold it, filtering software was still fairly primitive. Larkin (2002) described a study's finding that setting filtering software to strict pornography-blocking levels directly increased its rate of blocking sexual health information. The most restrictive settings blocked about $91 \%$ of pornographic content; at the lowest settings, $89 \%$ was blocked. But the amount of sexual health information blocked drastically increased from 1.4\% under less-restrictive settings to $24 \%$ when settings were at their strictest. A similar study published in 2005 (Lehmann, Cohen \& Kim) detailed conflicts between pornography-blocking efforts and inadvertently blocked health and medical information. A dermatology image source was being both inappropriately blocked for legitimate researchers from Great Britain's National Health Service, as well as inappropriately accessed by those seeking images of sexual organs. Attempts to block misusers affected medical professionals and researchers, requiring significant reworking of how technology was programmed to more effectively determine which users were abusing dermatology-oriented images (p. 437). Public libraries, however, do not have direct control over filtering software. Most filtering software is owned and created by private companies, and algorithms that filter content are proprietary. Public libraries do not have insight into these "black boxes" and cannot independently change settings; they must appeal to the vendors to adjust filters (Batch, 2014 \& 2015; Jaeger, et al., 2004).

Failures are not unheard of, even with today's more sophisticated versions of Internet filters. Overfiltering of acceptable content, and under-filtering of that which is not, continues. ALA's Internet Filtering: An Interpretation of the Library Bill of Rights, adopted in 2015, explains this in their reasoning for objecting to mandated filtering. ALA also points out that it is extremely problematic to limit all public library users to information deemed appropriate for minors. Even among minors, there are different levels of maturity, and what is acceptable for a sixteen-year-old to view may not be for a six-year-old child (Kranich, 2004, p. 15).

Furthermore, who determines what is or is not "harmful" or "acceptable" content? For example, should libraries' public computers censor photographer Robert Mapplethorpe, known for sexually charged material? Historically, some object to exhibiting his artwork (Deane, 2004; Neilson, 2010). Lawrence and Fry (2016) argue that in the context of patrons as "situated knowers", filters must be capable of mystical predictive and telepathic properties in order to be fully successful. Because each patron seeks information in a different context, and perceives content on an individual level, each patron has a unique concept of what should or should not be filtered. It is certain interactions with material that are objectionable.

Multiple cases of private interests dictating Internet content filtering exist, which lead to harmful biases. Software company's values are prioritized over those of the purchasing library and its community. Filters have blocked legitimate sites discussing Wicca spirituality, Muslim faith, and LGBTQ+ issues (ALA, 2015; Batch, 2014; Caldwell-Stone, 2013; Quillen, 2011). A Missouri library's filters blocked "occult"-categorized Internet content, and faced a federal civil suit (Patrick, 2013). Public schools and entire districts across the United States have faced lawsuits when students are unable to access information relevant to their education and scholastic research. Two Tennessee school districts directed their software providers to adjust filtering parameters so students may access websites with positive attitudes towards LGBTQ+ topics, previously allowing only sites with negative (potentially harmful) information, following the Franks v. Metropolitan Board of Public Education court case in 2009 (American Civil Liberties Union, 2009; Goldberg 2009; StortsBrinks, 2010). A student in Pennsylvania encountered similar problems in 2013; sites supportive of LGBTQ+ were blocked but condemning sites were only partially filtered (ACLU of Pennsylvania, 2013; States News Service, 2013). According to Quillen (2011), the American Civil Liberties Union (ACLU) contacted school districts in 24 states investigating excessive filtering practices.

As mentioned above, most Internet filtering software lacks transparency, and the algorithms or methods used to determine which sites to filter are considered proprietary (Batch, 2014 \& 2015; Jaeger, et al., 2004). This has led to inconsistencies in information made inaccessible, linked to modern filtering (Peterson, Oltmann \& Knox, 2017). Some open source software is available, but it is not always a public library's most efficient choice (Batch, 2014). 
The uncertainty shading the gradient of acceptable ideas is embodied in the unavoidably subjective Miller test guidelines (Tubbs \& Smith, 2018). The same is reflected in CIPA's third category of prohibited visual content-harmful to minors-listed without sufficiently specific instructions for identification. Peterson, Oltmann and Knox (2017) point out the lack of guidance in CIPA "for how stakeholders ought to evaluate if a visual depiction qualifies as obscene or harmful to minors" or for resolving and disputes that may arise when such decisions are made (p. 4587).

There is no legal definition for the term "harmful to minors" on FCC CIPA webpages, but the United States' Justice Department webpage guide for citizens on federal obscenity laws provides some explanation. Standards for obscenity are different when applied to minors. However, qualifications for determining when a "communication consisting of nudity, sex or excretion" is harmful to minors closely mirror Miller by tacking on the consideration of minors to each of the three criteria (Citizen's guide, 2015). The same subjectivity that plagues the Miller test thus plagues standards for establishing what is obscenity for or harmful to minors.

Libraries choosing to maintain a portion of public computers without filters or forgo E-rate discounts and leave all Internet access unfiltered face many complications. These come in forms such as trying to enforce policies prohibiting patron use of Internet pornography, while relying exclusively on library staff to catch incidents; satisfying other state or local laws dictating filtering and Internet policies; or selecting which persons may be allowed to view Internet pornography, and how to continue to accommodate all patron types. As a result, many public libraries prohibit computer users from viewing potentially objectionable content, regardless of implementation of Internet filters.

Whether or not it is generally harmful for adult patrons to access legal pornography-assuming that in the process no library equipment is damaged or illegal behavior is indulged in-is not discussed here. As explained above, interpretations of what is harmful or unacceptable visual content for a library environment vary widely; thus, libraries must delicately balance patron interests when writing policy. Rather, this research focuses on users' First Amendment rights, library policies and staff perspectives.

\section{Methodology}

An exploration of library policies and library employee experiences was required to understand how public libraries react to patrons viewing legal Internet pornography, while both protecting First Amendment rights and complying with federal and local laws. To adequately answer these research questions, data was accumulated by mixed-method research strategies, from a quantitative survey questionnaire and qualitative interviews. The two were conducted concurrently in 2019. Questions were drawn from previous coursework experience investigating a similar topic. Because data required was based on how patrons use public library computers, current US public library employees were recruited. Generally, libraries do not track or permanently record individuals' Internet browsing to protect privacy; gathering information based on employee experiences and system policies was most effective.

A 20-question online survey opened on August 4, 2019; responses were accepted until October 5, 2019. Links to the survey, a brief explanation of the research purpose, and researcher contact information were posted on a popular librarianship Facebook page three times during that period. Individual libraries contacted to request assistance with interviews were provided a link to the survey and a longer statement on research purpose and protecting participant and library anonymity. Links were distributed to all interview participants as well. During the collection period, 96 people who worked in a US public library in 35 states responded.

Qualitative interviews were more challenging to complete. Researcher efforts to find candidates were met with low success levels. Initially, the goal was to find two participants from each of 16 states, representing an equal geographic and very general political spread. Ideally, one interviewee would be from a larger, urban-setting library system and the other a smaller, more rural library system. Requests were sent to libraries and staff by libraries' email, Ask a Librarian, and Live Chats; multiple calls for participants were issued on the same librarianship Facebook group where links to the survey were posted. Very few 
responded, and few were non-automated or agreements to be interviewed. As it became clear it would be impossible to find enough candidates in a reasonable amount of time if the researcher remained selective about location, goals were refocused.

Ultimately, nine library employees took part in semi-structured interviews, conducted by phone call or Internet video conference. Each interview's audio was recorded and transcribed. Interviewees were asked to review transcripts, provide corrections where required, and subsequently grant approval for researcher use. Contents were analyzed for patterns, similarities and differences in experiences, library policies, filtering systems and implementation timelines. To protect anonymity, interviewees have been assigned pseudonym initials, and their specific libraries or library systems are not named. States and position titles are used.

\section{Quantitative Research}

The majority of respondents (58.3\%) said their policies do not allow patrons to view legal Internet pornography. A quarter (25\%) have policies that permit viewing under some conditions, and a small amount (5.2\%) allow viewing pornography without restricting conditions. One participant did not know their policy. The survey provided an "Other" option to write a response for those whose policies did not match selections provided. Unfortunately, there seemed to be some participant confusion. Responses indicated they did not know the difference between obscenity and legal pornography ("State law prohibits display of obscenity where a minor could view.”), did not see the question addressed legal Internet pornography exclusively ("Only legal pornography allowed"; "Child pornography is not allowed. It is illegal. Otherwise, patrons can view pornography if this [sic] wish.”) or were more concerned with demonstrating adherence to laws ("Follow CIPA for funding for public computers"; "State law says it's illegal to view where a minor can see, no policy"). A few responses explained policies did not explicitly mention pornography, but staff generally interpreted guidelines as prohibiting it on public computers ("There is no explicit policy about pornography but our computer use policy states that patrons cannot view visual materials that are disruptive to others (which generally involves porn)."; "there is no definition for pornography so we address disruptive behavior"). These were interpreted to fit provided answers, resulting in $63.5 \%(\mathrm{n}=61)$ respondents' libraries prohibiting pornography viewing, $29.2 \%(n=28)$ allowing viewing with some conditions, $5.2 \%(n=5)$ allow viewing unconditionally, and roughly $2 \%$ who do not know their policy or were unable to provide sufficiently clear answers.

Most participants agreed with their library's policy both professionally (86.5\%) and personally (82.1\%), without taking into account whether or not viewing legal Internet pornography is permissible.

Looking at three larger categories of legal Internet pornography permissibility policy statementsdon't allow any viewing; allow with some conditions; allow with no conditions-consistencies between agreement on professional and personal levels are more interesting and nuanced. Staff whose libraries did not allow patrons to view legal pornography were slightly more likely to agree on a personal level $(n=56)$ than on a professional level $(\mathrm{n}=51)$. Library policies allowing patrons to view pornography garnered more professional consensus than personal-for both policies with conditions for viewing Internet pornography ( $n=26$ versus $n=18^{2}$ ) and policies without conditions for viewing Internet pornography $(n=4$ versus $n=3)$. This tendency for professional opinions to run slightly in favor of policies that allow pornography, and for more to disagree on a professional level when it is prohibited, hints at the potential intellectual conflict presented by First Amendment protection of pornography.

Three questions measured participants' feelings towards library roles supporting patrons' rights to view pornography by asking them to indicate how much they agreed on a Likert scale from strongly agree to strongly disagree with the statements "Filtering legal Internet pornography is a form of censorship"; "Libraries should support censoring all legal Internet pornography on their premises, regardless of viewers' age"; and "Patrons' right to view legal Internet pornography in public libraries should be protected by the

2 One person whose library permits patrons to view pornography under some conditions chose not to supply their personal opinion. 
library". The term "censor” was deliberately chosen; library employees often have strong feelings towards censorship.

Results were mixed. A large portion selected neutral for all three: $20.8 \%, 33.3 \%$, and $20.8 \%$, respectively. Nearly half, 47.9\%, strongly agreed or agreed that filtering legal Internet pornography is a form of censorship, yet only $25.9 \%$ strongly agreed or agreed that libraries should protect patrons' right to view it. That number is closer to those who strongly agreed or agreed libraries had an obligation to censor pornography, $29.1 \%$, than strongly disagreed or disagreed, $37.5 \%$. There is a 10.4 percentage point difference between those who felt filtering pornography is censorship and those who did not support censoring pornography. A greater difference of 22 percentage points exists between those who think filtering pornography is censorship and those who think libraries need to support patrons' right to view pornography. Though each statement increases implied support of allowing patrons to view Internet pornography in public libraries, the percentage of respondents who appear to agree with that sentiment is not strong enough to form definitive conclusions.

Participants were asked to rate how strongly they felt, as information professionals, that the First Amendment protected patrons' right to view legal Internet pornography in public libraries on a scale of one to five, one representing not at all protected and five fully protected. Separated from library policy factors, this question focused instead on legal Internet pornography's status as a protected form of speech or expression. Fewer believed viewing legal Internet pornography in public libraries is protected by the First Amendment than those who did not or were ambivalent (see Figure 1).

13. On a scale of 1-5, how strongly do you feel, as an information professional, that viewing legal Internet pornography in public libraries is a right protected by the First Amendment, which guarantees the freedom of speech/expression?

96 responses

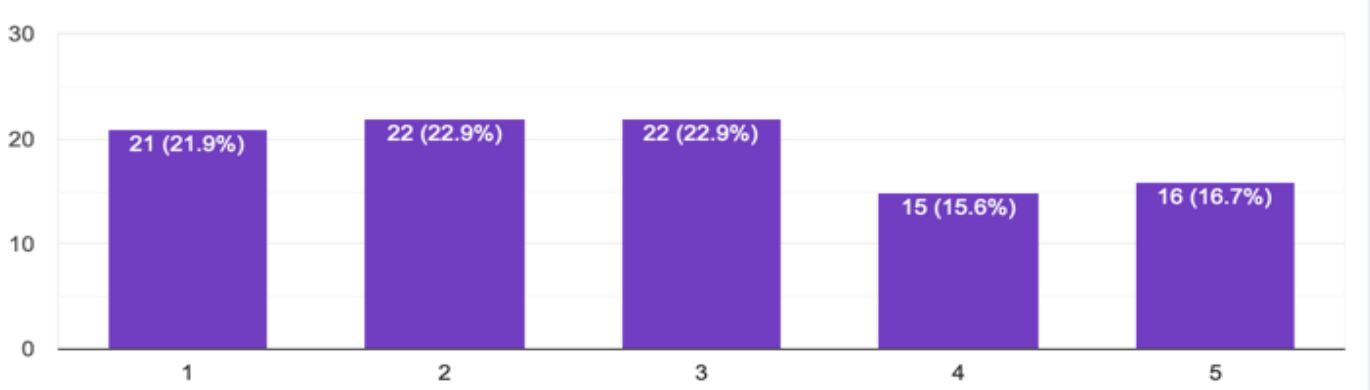

Figure 1.

An analysis of those who appeared to lean towards professionally agreeing with permitting patrons to view legal Internet pornography, based on agreement with policies that allow unconditional pornography viewing or conditional pornography viewing, and disagreement with policies that prohibit viewing legal Internet pornography, was performed by comparing those answers to individual ratings of how much they perceived the First Amendment protects patrons' right to view legal Internet pornography in public libraries (see Table 1). If anything, these numbers expose the issue's complexity. Respondents who seemed to support allowing patrons' right to view pornography did not always give a high rating for First Amendment protection. And some of those whose personal opinion of library pornography policies contrasted with their professional opinion had the strongest feelings about legal Internet pornography's protection in public libraries under the First Amendment. 


\begin{tabular}{llllll}
\hline & \multicolumn{5}{c}{ Rating of Protected Status, $\mathbf{1}$ (Not at All) to $\mathbf{5}$ (Fully Protected) } \\
\cline { 2 - 6 } & $\mathbf{5}$ & $\mathbf{4}$ & $\mathbf{3}$ & $\mathbf{2}$ & $\mathbf{1}$ \\
\hline Professionally Agree with Allowing, No Conditions & 3 & 0 & 0 & 0 & 1 \\
Professionally Agree with Allowing, Some Conditions & 9 & 10 & 5 & 1 & 2 \\
Professionally Disagree with Prohibiting & 2 & 3 & 5 & 0 & 0 \\
\hline
\end{tabular}

Initial furor surrounding the passing and subsequent Supreme Court upholding of CIPA has calmed, leaving the law generally unknown. A survey question asking if participants' libraries intentionally complied with CIPA to receive federal funding revealed it may be less relevant for some librarians or no longer a source of personal and professional conflict. Both the survey's introduction and a statement preceding that question provided information about CIPA and a link to the FCC's CIPA website. Yet 25\% of responses indicated participants were unsure how, or if, their employing libraries were CIPA compliant. The largest portion of responses, 37.5\%, showed libraries intentionally complied with both CIPA and other state/local laws. Slightly fewer disclosed intentional compliance with just CIPA-22.9\%. Libraries who comply with neither CIPA nor other state/local laws had the lowest number of participating employees, at $14.6 \%$ of responses.

Survey results show $18.75 \%$ of respondents working for 15 years or more were unsure of their libraries' compliance. Participants employed between five and ten years had the lowest rate of uncertainty at $17.24 \%$ and respondents working in public libraries between 10 and 15 years were more likely to be unsure at a rate of $29.41 \%$. The highest number of participants, $32.35 \%$, who are unsure of intentional CIPA and other state/ local law compliance have worked in public libraries for fewer than five years.

A large majority of respondents, $87.5 \%(n=84)$, have encountered patrons using library technology to access Internet pornography. Clearly, it is not a rare phenomenon. Though the survey did not address how recently incidents occurred, participants were asked to estimate frequency: a few times per year, a few times per month, a few times per week, or on most days. Most of the 84 who experienced patron pornography use selected a few times annually, 58.3\%. As the frequency of incidents rose, the number of estimates decreased; $23.8 \%$ said a few times a month, $10.7 \%$ a few times a week, and $7.1 \%$ on most days.

It was impossible to determine if the frequency of witnessing patrons viewing pornography was related to library policies allowing or prohibiting such behavior. None of the participants who reported their libraries permit viewing pornography unconditionally experienced incidents as rarely as a few times annually. However, because so few participants' libraries permit patrons to access Internet pornography using library technology, with or without conditions, relative to those who prohibit it, a relationship is difficult to extract from the data.

Survey data did not provide any recognizable relationship between states in which respondents work and whether library policy permits patrons to view legal Internet pornography. Participants whose libraries allow legal Internet pornography viewing, with or without restricting conditions, were located in 18 of 35 states. However, data does appear to suggest a link between population density and policies allowing legal Internet pornography. Participants were asked to select which term best described the area their library served: large or small metropolitan, large or small suburban, and large or small rural. In this analysis, categories have been limited to metropolitan, suburban, and rural to reduce potential individual perception of large or small. $25.42 \%$ of participants work for libraries serving metropolitan areas; $38.54 \%$ for suburban population centers, and $26.04 \%$ for libraries in rural communities. Only respondents' libraries located in metropolitan $(n=3)$ or suburban $(\mathrm{n}=2)$ areas allow patrons to watch legal Internet pornography unconditionally. But there were a few from rural libraries who indicated patrons were permitted to watch legal Internet pornography, with some limiting conditions, at a rate of $24 \%$. A similar rate of respondents' libraries was located in suburban zones: $27 \%$. But the greatest portion of participants (35.29\%) who work for libraries that let patrons watch legal Internet pornography, with some conditions, are in metropolitan areas.

Whether or not viewing pornography is allowed did not appear related to the behavior's existence. Among 12 respondents who have not witnessed it, five work in libraries that prohibit Internet pornography 
viewing, five where it is allowed with some conditions, one where there are no restricting conditions, and one who did not know the policy. It is interesting to note that of those library employees who indicated they have never encountered a patron using library technology to view Internet pornography, almost all $(\mathrm{n}=10)$ have worked in the public library sector for fewer than five years.

Media has played an integral role in bringing incidents of library patrons viewing Internet pornography to national attention (Deane, 2004; Peralta, 2011). The number of articles, and the dedication that some concerned citizens have for combatting these incidents (Rogers, 2014), are disproportionate to the number of complaints most participants reported they receive annually. Almost half, $42.7 \%$, claimed they received no complaints about their Internet pornography policies; many (39.6\%) said patrons had registered only one to three complaints per year. Dwindling from there, only $11.5 \%$ had about three to five annual complaints, and $6.3 \%$ estimated more than five.

Potential relationships between the frequency of pornography viewing incidents and number of annual complaints were investigated (see Table 2). The number of respondents who experienced patrons viewing Internet pornography decreases as the estimates of frequency of viewing incidents increases; it is impossible to identify a robust relationship with a sample set this small. Yet those who encounter patrons using Internet pornography on a monthly, weekly, or near daily basis were also participants who handle five or more annual complaints. Since a significantly larger number of participants find patrons using Internet pornography a few times a year than all others together, it is potentially relevant they do not claim to have more than five policy complaints per year. There is some tentative connection between permitting patrons to view Internet pornography and incident rate, suggesting a similar tentative connection may exist between frequency of incidents and policy complaints.

Table 2.

\begin{tabular}{lllll}
\hline & \multicolumn{2}{l}{ Estimated Frequency Encountering Patrons Viewing } & Internet Pornography & \\
\hline $\begin{array}{l}\text { Estimate of Complaints, } \\
\text { Annually }\end{array}$ & Few per Year & Few per Month & Few per Week & On Most Days \\
\hline 0 & 23 & 5 & 3 & 1 \\
$1-3$ & 23 & 8 & 3 & 1 \\
$3-5$ & 3 & 5 & 2 & 1 \\
$5+$ & 0 & 2 & 1 & 3 \\
\hline
\end{tabular}

79.2\% of participants reported their libraries use at least some Internet filtering software on public computers. Almost half (44.8\%) said all public-use computers have filters. 16.7\% indicated their libraries have filters on all public computers, with an option for adults to disable it; a roughly similar $17.7 \%$ work in libraries with filters on public computers designated for children only. However, there is minimal variation between the number of respondents who have not encountered patrons using Internet pornography and how their libraries use filtering software (see Table 3).

Table 3

\begin{tabular}{lllll}
\hline $\begin{array}{l}\text { Seen Patrons Access Por- } \\
\text { nography? }\end{array}$ & Filters on All Computers & $\begin{array}{l}\text { Filters on All Computers, } \\
\text { Adults Can Disable }\end{array}$ & $\begin{array}{l}\text { Filters on Children's Com- } \\
\text { puters Only }\end{array}$ & No Filters Used \\
\hline Yes & 40 & 14 & 14 & 16 \\
No & 3 & 2 & 3 & 4 \\
\hline
\end{tabular}

Among respondents who have encountered patrons viewing pornography and also work in libraries that do not use filtering software, most said incidents occur a few times annually. A fairly even number of incidents were estimated to happen on a monthly, weekly, or daily basis for all filtering levels (see Table 4), despite fewer libraries having filtering software that is either on children's computers exclusively or can 
be disabled by adults together, than those with filters on all public computers. Notably, participants who work at libraries that do not use any filters had a higher rate of encountering patrons accessing Internet pornography via library technology a few times a year than participants whose libraries have selective filtering policies.

Table 4

\begin{tabular}{lllll}
\hline Frequency of Encounters & $\begin{array}{l}\text { Filters on All Public Com- } \\
\text { puters }\end{array}$ & $\begin{array}{l}\text { Filters on All Computers, } \\
\text { Adults Can Disable }\end{array}$ & $\begin{array}{l}\text { Filters on Children's Com- } \\
\text { puters Only }\end{array}$ & No Filters Used \\
\hline Most Days & 2 & 1 & 1 & 2 \\
Weekly & 5 & 2 & 2 & 0 \\
Monthly & 6 & 5 & 6 & 3 \\
Annually & 27 & 6 & 5 & 11 \\
\hline
\end{tabular}

How employees handleincidents of patrons viewing Internet pornography was also investigated. Participants who received complaints $(n=56)$ were asked to describe actions taken. Some chose to not answer, resulting in 53 explanations. Most respondents' reactions to first-time incidents fell into several broad categories: pornography viewers were asked to stop or issued warnings (with escalations of repercussions possible); complaining patrons were informed pornography was permitted, and both parties were accommodated; pornography viewers were removed from public computers; pornography viewers were asked to leave; pornography viewers were banned on a permanent or temporary basis. Some answers were unclear on what follows initial reactions ("call security"; "we intervene, it's the law"; "Customer is mad [sic] aware of complaint") or how it might affect the patron viewing Internet pornography. Two respondents explained incidents might be handled differently by individual staff, leading to some variation; but those followed a similar pattern of warnings, computer privilege denials, and removal from premises.

By far, the majority of respondents' libraries first issue a warning or ask patrons to cease, at $47.17 \%$. The next most common tactic is explaining to complainants that the library permits pornography viewing and attempts to accommodate both parties (18.87\%). Removing pornography viewers from public computers follows, at $13.2 \%$ of the responses; asking the viewers to leave the library premises is close with $9.43 \%$. $5.66 \%$ of the participants' libraries ban pornography users.

Respondents were asked to estimate average age ranges of patrons involved in witnessed incidents. Ranges were under 18 years, $18-30$ years, $30-50$ years, $50+$ years, or none to their knowledge. ${ }^{3}$ Of the 84 who encountered patrons viewing Internet pornography, fewer ( $n=21$ incidents) estimated patrons to be under 18 than any other age range. 30-50 had the highest number $(n=72)$ followed by over $50(n=68)$ and then 18-30 $(\mathrm{n}=44)$. This implies minors are not the primary age group seeking Internet pornography.

Answers were analyzed for a potential connection between library policies that permit viewing pornography and library employees who encountered pornography-viewing patrons estimated to be aged under 18 years. Unfortunately, as only five respondents indicated their policies allow patrons to view legal Internet pornography, with no restricting conditions, it is hard to determine an exact relationship. Three of the five (or 60\%) estimated there were minors among pornography-using patrons. More significantly, $22.95 \%(n=14)$ of the participants whose libraries prohibit Internet pornography viewing included minors, unlike $10.71 \%(n=3)$ of the respondents whose policies allow patrons to view pornography under some conditions. It is also notable that none of the participants exclusively selected the under 18 age group.

With the exception of libraries that have filters on all public computers, with an option for adults to disable, the level of Internet filtering does not appear to affect the likelihood of minors accessing Internet pornography, with only $6.25 \%$ indicating they have seen such incidents. $20.93 \%$ of respondents who have filters on all public computers have encountered minors accessing Internet pornography. A slightly higher

3 A participant who claimed to have not encountered patrons using library technology to view Internet pornography did select age ranges; those have been omitted from these numbers in the interest of accuracy. 
percent of participants, $29.41 \%$, has encountered patrons under 18 years in libraries that have Internet filters on computers designated for children. The highest rate of respondents encountering minors work in libraries with no filters, $30 \%$.

\section{Qualitative Research}

During the same period that quantitative data was collected, interview participants currently employed by public libraries across mainland US states were sought. Interviewees were not selected based on any characteristics, categories, or classifications beyond present employment. Identifying features are intentionally obscured.

All but one interviewee work for libraries where viewing Internet pornography is largely prohibited. Though some of their libraries provide unfiltered public computers, they are not intended for that use. A few described policies that do not mention pornography specifically, but terminology intentionally implies it is forbidden.

"CS", an adult services specialist in a Wyoming county library, explained that their pertinent policy portion addresses disruptive behavior, or "other behaviors judged to be inappropriate by library staff." Additionally, CS clarified that library employees often cite copyright or software legal infringement, when applicable, for further support. CS was asked if this meant that if a patron was watching legal and legallyobtained pornographic content online, and no other patrons or staff objected, that patron would be allowed to continue. Though acknowledged an unlikely hypothetical situation, CS agreed that until any user or staff member took issue, a patron could. Internet filters are only on teen and children's computers despite policy basically banning Internet pornography. Notably, CS paraphrased part of the International Federation of Library Associations and Institutions (IFLA) Code of Ethics stating that libraries and staff should respect protecting minors without impacting adults' information rights.

Minors are not allowed to access unfiltered, adult computers without a guardian or a signed release informing guardians those computers can access anything. CS and other staff try to keep minors on ageappropriate computers, with machines designated for youth in grades kindergarten through sixth, and others for grades seventh through twelfth. Library staff makes an effort to do a grade or age check before a possible minor uses an unfiltered public computer. This is one system to help combat issues raised by those like Kranich (2004) and the ALA in objections to CIPA. Nonetheless, CS has only once encountered a patron attempting to view pornographic content during four and a half years of employment. CS believes it is more common on the first floor (CS works on the second), where public computers are not immediately visible to staff, and that there are incidents roughly "once a quarter, maybe once every four months or so." Library employees encounter patrons using Internet pornography infrequently enough that it is not necessarily mentioned in training; most learn how to handle it on the job.

Another participant, "JC", library assistant senior in a New Mexico city library, works as a library computer lab supervisor. Most of JC's library's computers are in a lab open to all ages. They have Internet filters, deliberately installed for recent CIPA compliance, with different levels for patrons of different ages (there are three computers without filters, intended for job applications or genealogical research). Staff can disable filters upon request, but JC generally asks for a reason. Patrons are not permitted to view Internet pornography. JC stated there was not "a policy specifically about [...] Internet content; it is a subsection of disruptive behavior", which proved fairly common.

JC explained that at one point filters arbitrarily blocked AOL.com sites. Function was not the cause; filters "let Hotmail through, it let Yahoo through, but for some reason AOL triggered it". In this clear case of inappropriate content blocking, JC's library was able to adjust filtering software, but patrons likely would not feel embarrassment or shame requesting assistance to access AOL websites. As pointed out by Jaeger, et al, (2004), some sensitive personal issues like health or sexuality may be impossible to research and difficult to approach staff about accessing. Furthermore, JC's library's software "is not sophisticated enough to filter images off of Google Images search”, displaying images from content normally blocked using other browsers or general Google search functions. This is a huge oversight-pornographic images are legislation's main concern. 
Similar to CS's library, JC's has different filter levels based on patron age, automatically enabled using age-identifying library cards. Non-members can obtain age group specific guest passes. In significant contrast to CS, JC has encountered patrons using public computers to access Internet pornography about three times-during nine months of employment-lending credence to arguments that filters may be ineffective or inefficient. JC still estimated it occurred infrequently.

According to "MB", head of reference for a Rhode Island city public library, librarians should be aware "filtering software [...] that we use is imperfect. Like, grossly imperfect." MB's library is a member of a consortium that uses Internet filters in compliance with CIPA and allows adult patrons to request a password or library staff assistance to disable it. When asked if public libraries' filtering Internet content could be a violation of patrons' First Amendment rights, MB explained "that, yes, it very well might be, and that is why we need to have the ability to disable the filter at any time. [...] We don't start the computers up in the morning and disable them, but we also don't say no when people ask. Or grill them about what they're doing."

Acutely aware of public libraries' computer services role in breaching the digital divide, MB recognizes the necessity of filtering and restricting certain content means libraries are "not really giving them everything that they need or want". With over a decade of field experience, MB feels conflicted about filters and how they might infringe on First Amendment rights. Still, MB emphasized the importance of CIPA compliance and how prohibiting patrons from accessing certain content makes the library "a place where everyone feels comfortable." Other interviewees voiced similar ideas; interests of the few Internet pornography viewers cannot outweigh those of patrons at large. In the same way, patrons who have a strong, unpleasant odor or talk to themselves, are among "so many situations in a library where one could be potentially uncomfortable.” MB sees libraries "trying our very best, but it being an imperfect [...] situation" where library staff must intervene. In MB's library, pornography viewing incidents-of which staff is made awaredo not occur more than a few times annually.

A library location's level of patron or computer-user activity does not appear to be a factor affecting the frequency staff encounters patrons using Internet pornography. "KA", a reference librarian for a large Texas city system, works in a busy branch with active Internet workstations. But during the past two years in a new building KA has not seen any Internet pornography. KA's library prohibits patrons from accessing "explicit sites on any workstation or any personal electronic device used on the library property", and patrons must agree to abide by library rules before using computers or Wi-Fi. Both filtered and unfiltered Internet-accessing computers are available. Unfiltered stations have privacy screens preventing passers-by from seeing user activity. This may shield patrons who violate library policy and visit sexually explicit or pornographic websites, but KA explained screen hoods are intended to protect privacy for sensitive information needs, like online banking or personal information displays. Ethical standards prohibit staff from monitoring user activity, so unless patrons are engaging in disruptive behavior while viewing Internet pornography, it may transpire unnoticed.

KA indicated Internet pornography presents intellectual and ethical dilemmas in a public library. Just as "you can't use obscene language at the library", explains KA, "I think it's fair to ask people not to access pornographic websites". Furthermore, KA said "I don't think that librarians are here to dictate what people can and cannot view in the library, particularly if they're not bothering anyone else. But, if their behavior or their content is something that's bothering other people, [...] we have an obligation to get involved, to make the library welcoming to everybody." KA's words mirror MB.

In one of the most memorable experiences shared, KA described when a patron with disabilities that make computer use difficult approached library staff for help learning how to find sexually explicit material. Though KA is concerned "the creation and consumption of pornography contributes to human trafficking" and agrees with the policy prohibiting Internet pornography, KA recognized on a professional level that the patron was basically interested in improving computer literacy, and "simply showed him how to do regular Google searches for general topics, then how to search the image gallery". In compliance with ethical standards, KA and colleagues did not "monitor him to see if he did inappropriate searches" later. This is an incredible example of how public libraries cross the digital divide. Even though some Internet content may be banned or blocked, and some librarians may disagree, those like KA will find ways to accommodate 
patrons. The current system is imperfect, but new technology services like lending hot spots for at-home use are becoming more widely available, enabling private access to Internet without restrictions and potentially greater freedom of expression.

Two interviewees who have worked in public libraries for over 15 years shared similar experiences from before widespread implementation of filters or other content-blocking software. "MG" and "DT" are reference librarians for larger city library systems.

MG described that era as the "Wild West" in his North Carolina library. Policy prohibited patrons from viewing Internet pornography, but enforcement was left exclusively to library staff who encountered it. MG's system later moved to a bandwidth shaper, which identifies websites categorized as pornography, "and squeezes [them] into so little bandwidth they'll just never load. They'll never load in a thousand years. And that was remarkably effective.” Pressure exerted by local media, community and government eventually led to implementing Internet filters because some parties learned that bandwidth shaping did not technically block pornographic content. Now, MG says they "basically don't see porn on computers". But before, "it was every day, multiple times a day, all year long", despite policies that warned patrons viewing Internet pornography was prohibited. In MG's library, these patrons were "almost always men”, of varying ages. MG's library represents a case of filtering success.

DT recounted that the day the Utah library first implemented filters they learned the library unwittingly supported the pornography industry. Evidently, users were uploading DVD videos to websites. When these were no longer accessible, DT was asked to disable the filter-even offered a substantial bribe. According to DT, it was a relief that filters could not be deactivated and result in an uncomfortable situation. Even now, DT said patrons frequently view Internet pornography, regardless of filtering. In one week, DT was forced to confront not only a person using Internet pornography every day, but also people masturbating. DT says it is a common problem.

DT's narrative diverges from MG's in that in DT's library, encountering patrons using Internet pornography is still commonplace. Additionally, in DT's experience, Internet pornography viewers represent wider demographics, though women are less common and often part of a couple.

Notably, both said that allowing Internet pornography on public computers creates a "hostile environment", using the same phrase. It appears their experiences handling pornography users, complaints regarding them, and occasional extraordinary associated bad behaviors, have provided a perspective those approaching from a purely philosophical standpoint do not appreciate. DT explained a conversation with a coworker led to agreeing that Internet pornography, or viewing it, is not necessarily objectionable; instead problems arise "because all this stuff that surrounds it". Both MG and DT support the First Amendment and freedom of speech and expression. MG also works "for an institution that is [...] quite devoted to First Amendment principles". These are not librarians representing a niche interest in limiting patrons from accessing information or enjoying freedom of speech.

Interviewees sometimes showed a tendency to support policies best reflecting their communities' values. Participants "LH" and "JG" represent two ends of the spectrum. $\mathrm{LH}$, a reference librarian in an Arkansas town, described filtering and repercussions much stricter than most participants. All public-use desktops and Chrome Books are heavily filtered; LH estimated during about four years of employment, there have been fewer than ten Internet pornography viewing incidents. In this library, patrons who violate Internet pornography policies are banned from computers for a full month on the first offense. A second offense merits a lifetime ban. Staff records occurrences with screen shots and filed reports. LH observed the library is located in a "very conservative town. So, it's also just natural instinct [...] to keep the computers locked down; that pornography is not to be viewed in the library", reflecting a "natural instinct of many people in [LH's] community". Throughout the interview, LH emphasized the library's interest in providing a family-centered environment safe for children.

Yet strict Internet filtering has caused issues, blocking sites that are not explicit, sexually or otherwise. LH said Cherokee Nation websites, gambling pages, and some mentioning marijuana are frequently blocked. This particular combination is an uncomfortable reminder that filters can reflect biases. Even in cases like LH's, where the library has a good relationship with their IT groups, it still takes time to restore access to blocked sites and may necessitate workarounds if not possible. When asked if prohibiting access 
to legal Internet pornography or if filtering software limiting access to online information was a violation of First Amendment rights, LH disagreed. Though the library is a public institution, and these pages are protected, library computers are "not their personal computers", and are "in the public eye"; library staff needs to ensure material like pornography is not viewed so others, especially children, do not see it.

JG is a library page in a Washington county library system, serving an urban population. JG also represents the only interviewee who works in a library where viewing Internet pornography is not explicitly or implicitly banned. ${ }^{4}$ During JG's six months in this library, JG has yet to witness patrons using Internet pornography. Basic training indicates that if patrons do not engage in illegal behavior, it is permissible. This does not mean JG's library does not have filtering software; in fact, there are different age-based filter parameters. Children's computers have a "max" setting, that blocks content commonly judged harmful to minors and also blog and email sites. Other public computer stations have two settings based on library card information for those under 17 or those 17 and older. Adult patrons who request filter deactivation do not need to provide reasoning. This is also yet to happen to JG, who is "pretty sure that would violate our privacy policy" to ask for justification. If so, the Washington library's policy recognizes and respects a point of contention many have with CIPA.

As a relative newcomer to the field, JG is still forming opinions, and was unsure about making a firm statement on how filtering or banning legal Internet pornography coexists with First Amendment rights. Currently, JG does not object to legal Internet pornography, if "it is an adult viewing that, and they're not being disruptive to other library members". In terms of filtering, JG sees both sides of the argument, that "there is so much scary stuff on the Internet [...] that could be traumatic" to children-but it is "a parent's or guardian's job to [...] be responsible for what their kids are viewing”; library staff are not babysitters and do not act in loco parentis. So, similar to how other children's section materials are age appropriate, filtering Internet content on children's computers for age appropriateness is best practice. For adults, JG says "people have the right to view whatever they want", and government agency-regulated filtering is abused around the world. "That's where I'm landing now", JG explained, "I know I have a lot to learn and a lot to experience.” In light of what MG and DT shared, it is entirely possible that JG will alter that stance.

\section{Comparison and Discussion of Qualitative and Quantitative Data}

Interpretations of data from the quantitative survey prompted some observations. Most easily extrapolated, given the number of participants who witnessed patrons accessing Internet pornography with library technology, is that filters do not seem to be as effective a barrier as intended. In fact, the expectation that libraries with no Internet filters or filters only on designated children's computers would have a higher frequency of incidents was not met. Tables 3 and 4 may suggest that the most effective filtering software implementation strategies for reducing pornography use are to install filters on public computers but allow adults to disable them.

Similarly made clear is that data points indicate that at some point, public library employees are likely to witness a patron using Internet pornography, regardless of filters, rules, or policies. Across a variety of prevention methods, almost all participants witnessed an incident, particularly those employed more than five years.

Because CIPA was challenged by the ALA and caused many initial investments in filtering software, a reasonable expectation is that library employees in the field at that time would be aware of employers' intentional compliance. Therefore, participants who have worked in the public library sector since the 2004 CIPA compliance deadline-or those in the field 15 years or more-would presumably be aware of their libraries' intentional compliance. Survey results did not support this theory, revealing a higher rate of uncertainty only among those employed fewer than five years.

The aim of laws like CIPA is to protect minors from material that may be deemed harmful. But as gathered data indicates, patrons still access Internet pornography via public library technology. Numbers

4 Of the five survey respondents who work for libraries that permit patrons to view legal Internet pornography without limiting conditions, three are located in Washington. However, this is not necessarily indicative of any state-based trends. 
suggest that policies designed to protect children from seeing online sexual imagery are not more effective when they include banning Internet pornography. The lack of a meaningful difference in rates of library employees witnessing minors accessing Internet pornography between libraries with no filters, filters on all public computers, and filters on children's computers only also suggests it is not the filters that prevent patrons under 18 years from accessing Internet pornography.

Qualitative data provided some insight into trends seen in the quantitative data. Others reflected patterns leading to the above tentative conclusions. Among them, a few stand out: most participants could describe an incident in which they encountered a patron using library technology to view Internet pornography or were asked to intervene in such a situation on behalf of another; employees working in the public library sector longer are more familiar with CIPA and have had more interactions with patrons viewing Internet pornography; participants supported the ideal of free and complete information access but recognized a necessity to sometimes curb it, or a desire to protect everyone's comfort. In particular, protecting minors from exposure to pornographic or sexual images was a prevalent concern shared by almost all participants.

Nuanced information from the interviews provides support for some prior research the introduction discussed; imperfect filters, inherent variability of what individuals find offensive or obscene, struggles to protect vulnerable people without limiting the ability to discover information.

Another pattern quickly revealed was library policies addressing unacceptable Internet viewing under either a disruptive behavior heading, or as part of an Internet conduct section. Direct reference to Internet pornography was less common among participant's policies than one might expect given the relative frequency of incidents.

Both interview and survey data indicated filters are not sufficient to completely prevent patrons of any age group from viewing Internet pornography. A large majority of survey participants, $87.5 \%$, and most interviewees revealed that they have encountered patrons using library technology to access Internet pornography. The likelihood of an employee witnessing these incidents appears to increase the longer one is employed. More survey respondents who worked in a public library for fewer than five years have not yet witnessed a patron viewing Internet pornography; so too with interviewees who have worked in public libraries for shorter periods, such as JG (six months) or KA (two years). That JG had yet to encounter anyone viewing Internet pornography is also significant, because legal Internet pornography is permitted in JG's library system.

A primary difference between quantitative and qualitative information is the demonstration of decisiveness regarding pornography's protected status as a First Amendment right and its permissibility in public institutions, namely public libraries. This was no doubt due to the different nature of the tools-in interviews, participants can articulate more complex and faceted ideas, and not required to select preprovided, specific answers. MG and DT presented concrete opinions, unequivocally opposed to permitting Internet pornography, but still had accompanying detailed explanations. Attempts to quantify this using Likert Scale survey questions revealed variations across the field but not the same depth of reasoning.

Separate, yet related, is unacceptable behavior associated with pornography viewing. Masturbation is unquestionably illegal in a public library. DT is not the only participant who indicated masturbation concerns. Two survey responses mention it in answers about actions taken when a patron is found using Internet pornography; a third implies it as "lewd behavior". If similar sexual acts, illegal in public places, are paired with viewing Internet pornography in libraries too frequently, banning patrons from accessing it is understandable. But very few respondents in either survey or interviews broached the subject which may mean it is atypical in most libraries.

\subsection{Recommendations and Concluding Statements}

Given the divisive nature of the topic, and the incredible variation of perceptions across the country, it is impossible to hand out a proscribed policy template to appease all parties. However, there are a few statements supported by this research. 


\subsection{Employees Will Likely Encounter Internet Pornography Viewing}

At some point, public library employees are likely to encounter a patron using library technology to access Internet pornography. The longer an employee works in a public library, the more likely this becomes. Filtering software, policies and laws do not appear to have a significant effect on the likelihood. Participants who described the most restrictive filtering and policy wording also frequently witnessed patrons viewing Internet pornography. Geographic location is similarly not indicative of if or how often patrons may be found viewing pornographic content.

\subsection{Policy Must Reflect and Respond to Inevitable Internet Pornography Incidents}

Therefore, public libraries need to write policy that clearly states their position on the permissibility of using library technology to view legal Internet pornography. In case this is seen as distasteful, or potentially causes external parties to react negatively by drawing attention to the issue, and therefore omitted from policies, library administration must be clear in training. Any library staff who may be expected to handle a patron or patron complaint, or frequent public computer areas, should know exactly how to react to these situations and what, if any, repercussions exist. In both libraries like DT's, where incidents are common, or CS's, where they are not, training did not prepare staff. A unified employee response, with specific wording or policy interpretations to support, will be easier for a fractious or upset patron to accept. Consistent handling and respect for all parties involved-even those who may violate policies in uncomfortable wayshelps establish confidence and decreases the risk of someone going to the press, city councils, or other outside groups to draw attention to an incident.

\subsection{Policies Must Respect Community Opinions and All Laws}

Local and community attitudes should be taken into account when crafting policies regulating use of legal Internet pornography. Conservative-leaning populations were mentioned by both survey and interview participants as reasons behind stricter policies. Public libraries frequently rely on taxpayer financial support, who expect community standards to be respected.

Policies and practices affect what protected speech patrons can access. A specific definition of prohibited material needs to be provided to vendors or other stakeholders developing filtering software parameters. This can help decrease chances that certain categories of protected speech are not inadvertently blocked and ensure decision makers are aware of the full range of effects filtering may have on information accessibility. Without customer-provided guidelines, material blocked may reflect the values and priorities of a private company rather than a library's community.

It is also essential that policies determining how patrons may or may not use legal Internet pornography follow all laws. CIPA's regulations can be ignored by library systems willing to forgo certain federal funding. But state or regional legislature may place unilateral restrictions on who may access legal pornography, when, and how. It may also require public libraries to follow guidelines for filtering (NCSL, 2018).

\section{Conclusions}

Ideally, public libraries would allow all people access to any legal Internet content that is not harmful to library property. For individuals, it is interactions with content, instead of the material, that is inappropriate (Lawrence \& Fry, 2016). Patrons capable of viewing legal Internet pornography without disturbing others or breaking laws could be accommodated. And yet, libraries, though public institutes, can and do have rules of conduct. Arguably, it is a person's First Amendment right to bathe as infrequently as they choose, or use racist, aggressive language. But these behaviors are prohibited in many public libraries. They disturb 
and upset fellow patrons, and library employees are trained to handle these situations. If library systems choose to see patron use of legal Internet pornography similarly, it is logical to train employees and write comprehensive policies similarly. Pornography is abundant online, and perfect filtering software has yet to be created. Patrons will find pornography if they want to search for it; libraries need to know what to do in advance.

Acknowledgements: The author would like to acknowledge Reagan Callahan and Colleen Forbes, University of Washington iSchool MLIS candidates, for their assistance with compiling and organizing research literature and recruiting participants.

\section{References}

ACLU of Pennsylvania. (2013). ACLU demands PA school district stop use of discriminatory internet filters. Retrieved from https://www.aclupa.org/en/press-releases/aclu-demands-pa-school-district-stop-use-discriminatory-internet-filters

American Civil Liberties Union. (2009). Franks v. metropolitan board of public education. Retrieved from https://www.aclu. org/cases/franks-v-metropolitan-board-public-education?redirect=cpredirect/39346

American Library Association. (2015). Internet filtering: An interpretation of the library bill of rights. Retrieved from http:// www.ala.org/advocacy/intfreedom/librarybill/interpretations/internet-filtering

American Library Association. (2010). The children's internet protection act (CIPA). Retrieved from http://www.ala.org/ advocacy/advleg/federallegislation/cipa

Auld, H., \& Pierce, J. B. (2003). Filters work: Get over it. American Libraries, 34, 38-42. Retrieved from https://www.jstor.org/ stable/25648629

Batch, K. R. (2015). Filtering beyond CIPA: Consequences of and alternatives to overfiltering in schools. Knowledge Quest, 44(1), 60-66. Retrieved from https://search.proquest.com/docview/1712288771

Batch, K. R. (2014). Fencing out knowledge: Impacts of the Children's Internet Protection Act 10 years later. ALA Office for Information Technology Policy \& Office for Intellectual Freedom.

Caldwell-Stone, D. (2013). Filtering and the First Amendment: When is it okay to block speech online? American Libraries, 44, 58-61. Retrieved from https://search.proquest.com/docview/1364693976

Children's Internet Protection Act (CIPA). (2011). Retrieved from https://www.fcc.gov/consumers/guides/childrens-internetprotection-act

Children's internet protection act, (1999). Retrieved from https://www.congress.gov/bill/106th-congress/senate-bill/97/text

Chmara, T. (2010). Minors' first amendment rights: CIPA \& school libraries. Knowledge Quest, 39(1), 16-21. Retrieved from https://search.proquest.com/docview/763162064

Citizen's guide to U.S. federal law on obscenity. (2015). Retrieved from https://www.justice.gov/criminal-ceos/citizens-guideus-federal-law-obscenity

Deane, G. (2004). Public libraries, pornography, and the damage done: A case study. Library Administration \& Management, 18(1), 8-13. Retrieved from https://search.proquest.com/docview/216643033

Fix, M. P. (2016). A universal standard for obscenity? the importance of context and other considerations. Justice System Journal, 37(1), 72-88.

Goldberg, B. (2009, June 9). Tennessee schools unblock LGBT websites following lawsuit. American Libraries Magazine Online, Retrieved from https://americanlibrariesmagazine.org/tennessee-schools-unblock-lgbt-websites-followinglawsuit/

Jaeger, P. T., Bertot, J. C., \& McClure, C. R. (2004). The effects of the Children's Internet Protection Act (CIPA) in public libraries and its implications for research: A statistical, policy, and legal analysis. Journal of the American Society for Information Science and Technology, 55(13), 1131-1139.

Kranich, N. (2004). Why filters won't protect children or adults. Library Administration \& Management, 18(1), 14-18. Retrieved from https://search.proquest.com/docview/216642342

Larkin, M. (2002). Pornography-blocking software may also block health information sites. The Lancet, 360(9349), 1946.

Lawrence, E., \& Fry, R. J. (2016). Content blocking and the patron as situated knower: What would it take for an internet filter to work? The Library Quarterly, 86(4), 403-418.

Lehmann, C. U., Cohen, B. A., \& Kim, G. R. (Jan 1, 2005). Management of pornography-seeking in an online dermatology atlas: Adventures in the skin trade. Paper presented at the AMIA Annual Symposium, 2005, 435-439. Retrieved from https:// www.openaire.eu/search/publication?articleld=od____ 267::6fcdb8e596b2a705ca35f08561a25202

National Conference of State Legislatures. (2018). State internet filtering laws. Retrieved from http://www.ncsl.org/research/ telecommunications-and-information-technology/state-internet-filtering-laws.aspx

Neilson, J. (2010). Freedom of expression, obscenity and the community standards test. Southwest Philosophy Review, 26(1), 171-179. 
Obscenity. (2015). Retrieved from https://www.justice.gov/criminal-ceos/obscenity

Patrick, R. (2013). Missouri library agrees not to block witch websites. Retrieved from https://www.stltoday.com/news/ local/crime-and-courts/missouri-library-agrees-not-to-block-witch-websites/article_5f3ec8c8-b490-5479-a02d4e7f2922e9d3.html

Peralta, E. (2011). Pornography is protected speech at New York public libraries. Retrieved from https://www.npr.org/sections/ thetwo-way/2011/04/25/135707937/pornography-is-protected-speech-at-new-york-public-libraries

Peterson, C., Oltmann, S. M., \& Knox, E. J. M. (2017). The inconsistent work of web filters: Mapping information access in Alabama public schools and libraries. International Journal of Communication (Online), 4583-4609.

Pornography. LII/Legal Information Institute. Retrieved from https://www.law.cornell.edu/wex/pornography

Quillen, I. (2011). ACLU puts pressure on districts to ease internet filtering; ACLU puts legal pressure on districts to open filters on LGBT material. Digital Directions, 5, 30-33.

Rogers, K. (2014). Why librarians are defending your right to watch porn at the library. Retrieved from https://www.vice.com/ en_us/article/wnj4ey/why-librarians-defend-the-right-to-watch-porn-at-the-library

Skaggs, J. A. (2003). Burning the library to roast the pig? online pornography and internet filtering in the free public library. Brooklyn Law Review, 68(3), 809-852.

States News Service. (2013, Feb 27). Governor Mifflin school district and filtering of LGBT online content. States News Service. Retrieved from https://link-gale-com.offcampus.lib.washington.edu/apps/doc/A320596978/AONE?u=wash_ main $\&$ sid $=$ AONE $\&$ xid $=$ e $7685 f 00$

Storts-Brinks, K. (2010). Censorship online: One school librarian's journey to provide access to LGBT resources. Knowledge Quest, 39(1), 22-28.

Tubbs, D. L., \& Smith, J. S. (2018). Pornography, the rule of law, and constitutional mythology. Harvard Journal of Law \& Public Policy, 41(2), 499-552. Retrieved from https://search.proquest.com/docview/2040740702 